'Departamento de Medicina Interna, Clínica Las Condes, Santiago, Chile

Lo Fondecilla 4412, Las Condes, Santiago, Chile.

gacuna@clinicalascondes.cl

${ }^{2}$ Departamento de Enfermedades Infecciosas e Inmunología Pediátricas. Escuela de Medicina. Pontificia Universidad Católica de Chile. Santiago, Chile. cperret@med.puc.cl

\section{¿En qué consiste la infección humana por Virus Zika?}

\section{What is human infection with Zika virus?}

Expertos interrogados por Editor de la Revista Médica de Chile

GUILLERMO ACUÑA L. ${ }^{1}$, CECILIA PERRET ${ }^{2}$
E I virus Zika pertenece al grupo de los Flavivirus, al que pertenecen también el virus del Dengue y el de la fiebre del Oeste del Nilo.

Este y otros virus infectan al hombre por picadura de mosquitos del género Aedes, especialmente el Aedes aegypti pero también el Aedes albopictus, el cual a pesar de ser un peor vector tiene mayor resistencia y adaptabilidad a climas menos calurosos, lo que ha permitido la expansión de las áreas tropicales inicialmente comprometidas a zonas subtropicales como Florida (EE. UU.).

Después de inoculación, hay un período de incubación de 3 a 14 días. Los síntomas más comunes son fiebre ( $50 \%$ de los casos), rash cutáneo que dura aproximadamente 5 días (97\%), purito $(79 \%)$, cefalea $(66 \%)$ y conjuntivitis no purulenta (56\%).

No hay leucocitosis, ni trombocitopenia (característico del Dengue). En las etapas tempranas clínicamente no es distinguible de Dengue o Chikungunya.

La sintomatología desaparece en 4 a 7 días. No existe evidencia de una mayor susceptibilidad ni mayor gravedad en la mujer embarazada.

\section{¿En qué países del mundo y de América se han comunicado brotes?}

A pesar de que el virus se aisló por primera vez en África y luego circuló por el Sud Este Asiático y la Polinesia, actualmente se ha concentrado su actividad en las Américas, en especial Sudamérica (Brasil, Colombia, Venezuela) Centro América y el Caribe y últimamente se ha reportado actividad en el sur de Estados Unidos, en especial el sur de Florida (Figura 1).

\section{¿Qué complicaciones se han observado luego de la infección por este virus?}

Dos tipos de complicaciones han hecho que una enfermedad auto-controlada y de sintomatología menor, haya producido un alto impacto de temor en el mundo:

Compromiso neurológico: el virus tiene neuro-tropismo y se ha asociado a brotes de síndrome de Guillen Barré en adultos en las zonas donde la epidemia se ha desarrollado con fuerza. Según datos aportados por observaciones en la Polinesia, el Guillen Barré aparece en 1/4.000 casos de Zika.

Zika congénito: la gran alarma se ha producido por la infección transplacentaria del virus con posibles alteraciones en el desarrollo fetal especialmente del tejido cerebral asociado a microcefalia, calcificaciones intracerebrales y otras alteraciones cerebrales. También se ha evidenciado compromiso ocular de los fetos infectados. Hay evidencias epidemiológicas muy fuertes que confirman esta asociación, la cual se produce mediante los macrófagos intraplacentarios que sirven de reservorio viral. Se desconoce la frecuencia y los factores de riesgo asociados a la transmisión. El RNA del virus se ha detecatdo en la sangre, tejido cerebral y líquido cefalorraquídeo.

Por el momento y basado en la experiencia de la Polinesia se indica que la frecuencia de microcefalia asociada a la infección Zika va de 1-13\% siendo mayor el riesgo cuando la infección es durante el primer trimestre del embarazo, pero no hay claridad del posible daño en embarazos de segundo o tercer trimestre. El seguimiento de embarazadas con Zika en Brasil reportó 29\% 


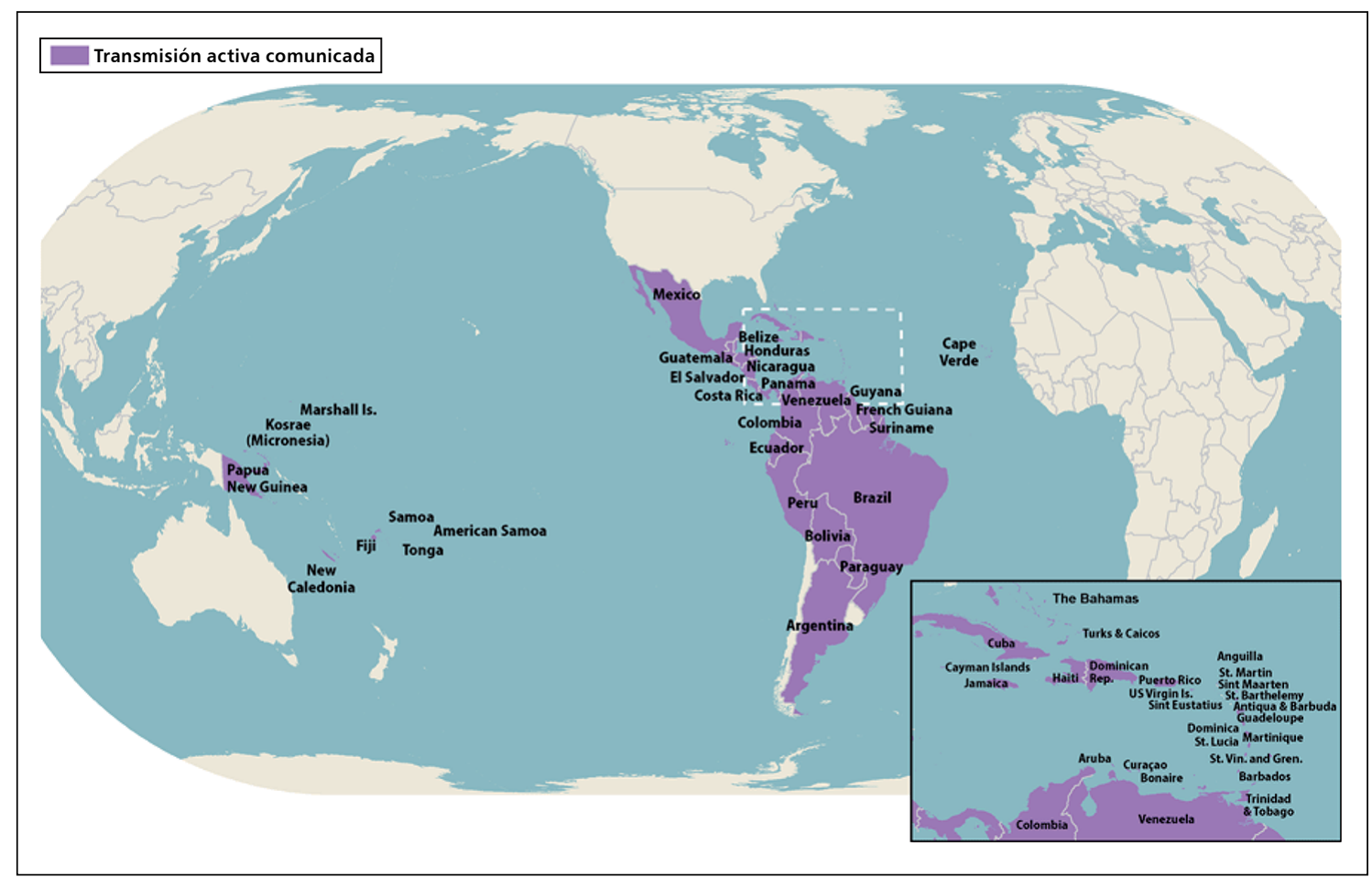

Figura 1. Mapa publicado por Center for Diseases Control, EE. UU., dominio público.

de fetos con complicaciones como microcefalia, mortinatos y otras alteraciones del SNC. Las complicaciones aparecieron incluso en infecciones adquiridas tardíamente como 32 semanas de edad gestacional.

La viremia en la persona que es infectada dura de 7 a 10 días, ese es el período de riesgo para el embrión-feto. La persona que tuvo una infección Zika en el pasado no tiene riesgo de dañar a un nuevo embrión, por lo que la preocupación es la mujer embarazada o que se pueda embarazar y presentar la infección durante el embarazo.

\section{¿Qué riesgos corren las mujeres embarazadas que visitan esos países?}

Como describimos previamente, una mujer embarazada, en especial en el primer trimestre del embarazo y que se infecta, tiene la posibilidad de transmitir vía transplacentaria el virus al feto con los posibles efectos en su desarrollo. No está claro el posible efecto si la infección se produce en etapas más avanzadas del embarazo.

\section{¿De qué otras formas puede trasmitirse el virus zika al hombre?}

Además la trasmisión por el vector, el mosquito del género Aedes que es por lejos la mayor y principal vía de trasmisión, se ha documentado trasmisión sexual y transfusional. También teóricamente podría existir trasmisión a través de leche materna y órganos trasplantados ya que se ha evidenciado la presencia de virus viable en distintos fluidos como saliva y orina y tejidos humanos

La vía de trasmisión sexual representa una novedad en la trasmisión de arbovirus pues no se había descrito en otros virus como dengue, chikungunya. Esta vía de trasmisión ha sido muy bien documentada existiendo trasmisión sexual principalmente del hombre a su pareja sexual con un solo reporte de trasmisión de mujer a hombre. La mayoría de los casos reportados han sido en hombres que han presentado infección sintomática de Zika, sin embargo, se ha documentado infección en una pareja en que el varón no presentó síntomas y trasmitió la infección ${ }^{8}$. La presencia del virus en 
semen se ha reportado por tiempo prolongado en varias publicaciones desde 24 hasta 188 días. Replicación viral ha sido encontrada hasta 24 días $^{9,10}$. Trasmisión sexual ha sido reportada hasta 41 días luego de que el caso índice fue sintomático ${ }^{11}$. El virus ha sido encontrado en el fluido seminal y también dentro de los espermatozoides ${ }^{12}$.

Virus Zika ha sido encontrado en leche materna de madres que se infectaron alrededor del parto. Sólo en uno de ellos se pudo documentar replicación viral lo que significa un potencial riesgo de trasmisión del virus por esta vía, sin embargo no se ha reportado infección de lactantes a través de leche materna ${ }^{13,14}$.

La trasmisión a través de transfusiones se ha documentado en Brasil en pacientes receptores de sangre y plaquetas ${ }^{15}$.

\section{¿Qué recomendaciones se le debe dar a mujeres embarazadas o con planes de embarazo que viajen a zonas de transmisión activa?}

La OMS (Organización Mundial de la Salud), en comunicado del 06/Sep/16 indica algunos puntos de interés. El virus se ha detectado en el semen hasta 24 días después del inicio de síntomas y el RNA viral (virus no viable) hasta 188 días post inicio de síntomas; se continúa estudiando la duración de excreción de virus Zika viable en líquido seminal. Considerando estos hallazgos se recomienda:

- Mujeres embarazadas o con planes de embarazo, abstenerse de viajar a zonas de transmisión activa (en especial primer trimestre pero en general en cualquier período del embarazo.

- Hombres y mujeres que vuelven de zonas de transmisión activa de Zika, evitar embarazo (anticoncepción) por al menos 6 meses desde su regreso y usar medidas de sexo seguro (condón) u abstinencia durante ese período.

- Parejas de mujeres embarazadas que vuelven de zonas de riesgo, abstenerse de relaciones o practicar sexo seguro al menos hasta el término del embarazo.

Estas recomendaciones son aplicables tanto a personas sintomáticas como asintomáticas.

\section{¿Cómo se puede prevenir la infección por este virus?}

Dado que la principal vía de trasmisión es a través de la picadura de mosquitos, la forma más eficiente para prevenir la infección es evitar las picaduras del mosquito. Para ello se deben utilizar repelentes que aseguren protección por varias horas como lo son aquellos que contienen DEET sobre $30 \%$ y picaridina sobre $20 \%$. Ambos repelentes pueden ser utilizados desde los 2 meses de vida y en las embarazadas. El repelente debe utilizarse durante las horas diurnas dado que el mosquito se alimenta entre el amanecer y atardecer.

La trasmisión sexual puede prevenirse mediante el uso de condón o abstinencia sexual por al menos 6 meses luego de una exposición de riesgo, ya sea viaje a zona de Aedes como contacto sexual con alguien que ha viajado a zona de riesgo.

Los bancos de sangre en la mayoría de los países no aceptan donantes provenientes de zonas de riesgo o contacto sexual con viajeros a esas zonas hasta 1 mes luego de la exposición.

\section{¿Cómo visualiza el futuro de la epidemia?}

Las epidemias tienen un curso natural en las cuales a medida que la población infectada y recuperada aumenta, se produce una barrera inmunológica en la cual el mosquito no encuentra pacientes con viremia activa y por otro lado si inocula el virus el huésped ya tiene inmunidad adquirida por una infección anterior y por lo tanto no enferma. Esto a podido verse en Brasil en donde en el período de las olimpiadas en Río de Janeiro no se reportaron nuevos casos de infección, también está bajando en Colombia y, sin embargo, se está reportando aumento de la infección en Centro América y Florida.

La epidemia puede afectar a zonas actualmente silentes como India y el Sud Este Asiático, donde existe el vector y debe existir una población actualmente no inmune.

Con lo aprendido hasta ahora en esta epidemia de Zika debemos considerar en agregar este virus a la lista de agentes causales de infección congénita y cambiar el tradicionalacrónimo TORCH por TORCHZ como lo sugiere el autor de Araujo ${ }^{17}$.

Es destacable que siendo una enfermedad trasmitida por mosquitos el virus Zika es capaz de cruzar las barreras de trasmisión más allá de las zonas geográficas que cuentan con el vector dada su capacidad de trasmitirse sexualmente.

Por otro lado, hay varias preguntas que aún no se pueden contestar:

- Tasa de infección fetal luego de infección materna. 
- Tasa en la cual la infección fetal se complica con microcefalia o síndrome congenito del Zika.

- Tasa de síndrome de Guillen Barré y si es mayor que con otras infecciones virales.

- Rol del trimestre de embarazo en que se produce la infección.

- Factores de riesgo o co-factores tanto para la infección fetal como para el síndrome de Guillen Barré.

- Duración máxima de la viremia después de la infección e infectividad desde la aparición de síntomas.

- Incidencia de la transmisión sexual.

- Rol de la infección asintomática y posibles complicaciones en pacientes sin síntomas.

- Efectos clínicos de diferentes cepas de virus Zika.

- Inmunidad luego de primo infección.

\section{Referencias}

1. Perret C. Virus Zika ¿culpable o inocente? Rev. Chilena de Infectología 2016; 33 (2): 189-90.

2. Anderson KB, Thomas SJ, Endy TP. The Emergence of Zika Virus: A Narrative Review. Ann Intern Med 2016; 165: 175-83. doi:10.7326/M16-0617

3. Oehler E, Watrin L, Larre P, Leparc-Goffart I, Lastere S, Valour F, et al. Zika virus infection complicated by Guillain-Barre syndrome-case report, French Polynesia, December 2013. Euro Surveill 2014; 19.

4. Musso D, Cao-Lormeau VM, Gubler DJ. Zika virus: following the path of dengue and chikungunya? [Letter]. Lancet. 2015; 386: 243-4.

5. Fauci AS, Morens DM. Zika virus in the Americas-yet another arbovirus threat. N Engl J Med 2016; 374: 6014.

6. Martines R, Bhatnagar J, Keating M. Notes from the field: evidence of Zika virus infection in brain and placental tissues from two congenitally infected newborns and two fetal losses-Brazil, 2015. MMWR Morb Mortal Wkly Rep 2016; 65: 159-60.

7. Prevention of sexual transmission of Zika virus Interim guidance update 6 September 2016 WHO/ZIKV/

\section{MOC/16.1 Rev.3}

8. Brooks R, Carlos MP, Myers R, White MG, Bobo-Lenoci T, Aplan D, et al. Likely Sexual Transmission of Zika Virus from a Man with No Symptomsof Infection-Maryland, 2016. MMWR 2016; 65: 915-6.

9. Matheron S, d'Ortenzio E, Leparc-Goffart I, Hubert B, de Lamballerie X, Yazdanpanah Y. Long-Lasting Persistence of ZikaVirus in Semen. Clin Infect Dis 2016; 63: 1264.

10. Nicastri E, Castilletti C, Liuzzi G, Lannetta M, Capobianchi MR, Lippolito G. Persistent detection of Zika virus RNA in semen for sixmonths after symptom onset in a traveller returning from Haiti to Italy, February 2016. Euro Surveill 2016; 21 (32): pii=30314. DOI: http:// dx.doi.org/10.2807/1560- 7917.ES.2016.21.32.30314.

11. Turmel JM, Abgueguen P, Hubert B, Vandamme YM, Maquart M, Le Guillou-Guillemette H, et al. Late sexual transmissionof Zika virus related topersistence in the semen. Lancet 2016; 387: 2501.

12. Mansuy JM, Suberbielle E, Chapuy-Regaud S, Mengelle C, Bujan L, Marchou B, et al. Zika virus in semen andspermatozoa. Lancet 2016; 16: 1106.

13. Besnard M, Lastere S, Teissier A, Cao-Lormeau V, Musso D. Evidence of perinatal transmission of Zika virus, French Polynesia, December 2013 and February 2014. Eurosurveillance 2014; 19: 20751.

14. Dupont-Rouzeyrol M, Biron A, O’Connor O, Huguon E, Descloux E. Infectious Zika viral particles in breastmilk. Lancet 2016; 387: 1051.

15.- Motta JF, Spencer B, Cordeiro da Silva S, Arruda M, Dobbin J, Gonzaga Y, et al. Evidence for Transmission of Zika Virus by Platelet Transfusion. N Engl Med 2016; 375: 1101-3.

16. Brasil P, Pereira J, Raja Gabaglia C, Damasceno L, Wakimoto M, Ribeiro Nogueira R, et al. Zika Virus Infection in Pregnant Womenin Rio de Janeiro-Preliminary Report. N Engl J Med 2016 Mar 4. [Epub ahead of print].

17. de Araújo TV, Rodrigues LC, de Alencar Ximenes RA, de Barros Miranda-Filho D, Montarroyos UR, de Melo AP, Association between Zika virus infection and microcephaly in Brazil, January to May, 2016: preliminary report of a case-control study. Lancet Infect Dis 2016 Sep 15. pii: S1473-3099 (16) 30318-8. doi: 10.1016/ S1473-3099(16)30318-8. [Epub ahead of print]. 